\title{
Archi-partiture. Sperimentazioni e corrispondenze fisiognomiche tra notazione musicale e architettura teatrale nel ' 900
}

\author{
Santi Centineo
}

\section{Abstract}

II paper ipotizza una relazione tra la notazione musicale, così come evolve nelle partiture della seconda metà del Novecento (in particolare quelle della musica elettronica e aleatoria) e progetti di architetture ipotizzate come contenitori per il loro ascolto, riscontrando in questo processo una natura di rispondenza fisiognomica.

L'indagine risulta corroborata dagli scritti teorici di compositori che dagli anni '50 in avanti hanno tentato di giustificare la propria ricerca, offrendo peraltro un quadro documentaristico autoptico.

Studio delle partiture musicali del Novecento e raffronto con spazi per la musica della seconda metà del XX secolo.

Constatazione di una reciprocità tra notazione musicale e architettura, in cui il comune denominatore è la rappresentazione, che, attraverso le partiture contemporanee, tenta di coniugare all'anticipazione acustico-musicale, la prefigurazione spaziale, in una sorta di sinestesia teoricamente rilevante, in quanto abbandona gli esiti sensoriali ed estetici, a favore di quelli teorici e concettuali.

Parole chiave

notazione musicale, spazi musicali, prefigurazione, sinestesia.

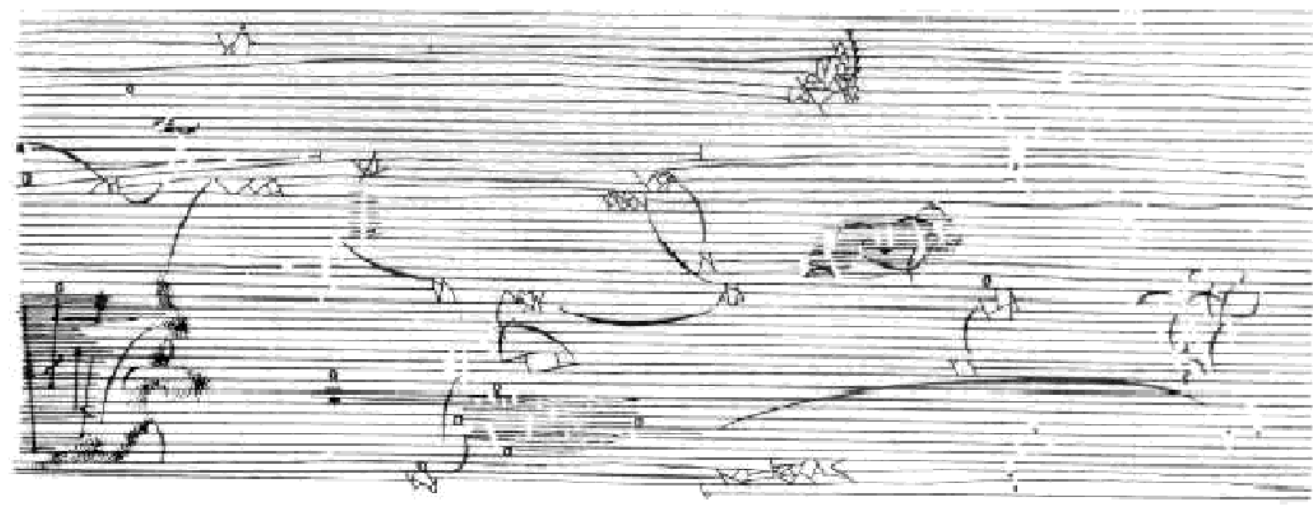


In tutti gli ambiti in cui sussiste una relazione tra la narrazione, ossia l'idea raccontata, e la sua concretizzazione formale (per esempio, la letteratura, la musica o l'architettura), tale connessione trova un momento cruciale nella possibilità della sua notazione.

La notazione in sé reperisce convenzionalmente alcuni elementi segnici, un alfabeto proprio, attraverso il cui ordinamento condiviso scaturisce un linguaggio e, come conseguenza, una diegesi: l'alfabeto nel linguaggio scritto (che trova il suo compimento nella lettura), la rappresentazione grafica in architettura (che prefigura e norma la costruzione), il sistema notazionale nel caso della musica (che prelude all'esecuzione strumentale).

In tutti i tre casi, sia che si voglia prescindere dalla realizzazione formale dell'idea rappresentata, sia che vi si voglia accedere, il processo che ne scaturisce, di natura intersoggettiva, parte dall'oggettività normata del codice, e si allarga alle sue possibilità interpretative, le quali si sventagliano nel beneficio della riproducibilità in serie. Ma, mentre per altre arti allografiche (fotografia, grafica, cinema o design) il processo seriale genera esemplari identici all'originale, nei tre casi sopra citati, il processo di completamento aviene attraverso il magistero interpretativo, la qual cosa non consentirà mai l'identicità di due esemplari.

Sul finire dell'Ottocento la musica romantica, al pari di tante altre arti, entra progressivamente in crisi. Non solo l'ideologia del romanticismo comincia a rivelarsi progressivamente fallimentare, ma un po' tutte le arti cominciano a interrogarsi su come accompagnare, rifiutare o osteggiare lo sviluppo industriale, scientifico e tecnologico che con esse inevitabilmente intende intersecare il proprio destino. Le Grandi Esposizioni Internazionali, a partire da quelle parigine per culminare con la londinese del | $85 \mid$, esprimevano appieno quel positivismo che sovente non faticava a degenerare in un'esaltazione salvifica del progresso, avviando peraltro un processo di ricerca estetizzante, volto a legittimare e legare a doppia mandata arti e industria.

La musica non aveva mancato di attestare con la propria presenza l'importanza di alcuni di questi momenti, anzi aveva contribuito in qualche modo a sancirne la legittimità. Hector Berlioz dirige ripetutamente orchestre di organico inusitato (oltre mille esecutori) in edifici industriali (primo fra tutti il Crystal Palace), sfoggiando l'uso del modernissimo metronomo elettrico, o di strumenti innovativi (il saxofono, ad esempio) o di ultima generazione (gli harmonium).

È l'inizio di un percorso di mercificazione e oggettivazione del percorso artistico, che porterà in breve ad una frattura, forse insanabile, tra la materialità dei contesti produttivi musicali e l'immaterialità della musica stessa.

I rumori del mondo moderno, provenienti dalle industrie, dalle macchine, dalle nuove frenesie, da nuovi oggetti e materiali, cambiano lo scenario e il paesaggio sonoro, alla base della natura imitativa, pur sempre insita nella musica.

Quando nel giugno del 19/3 Luigi Russolo presenta il suo 'intonarumori', al Teatro Storchi di Modena, si creò uno scalpore annunciato (fig. Ia).

Fig. I. a) Luigi Russolo presenta l'intonarumori insieme al suo assistente Ugo Piatti (1913); b) Luig Russolo, Risveglio della città per intonarumori partitura (19|3).
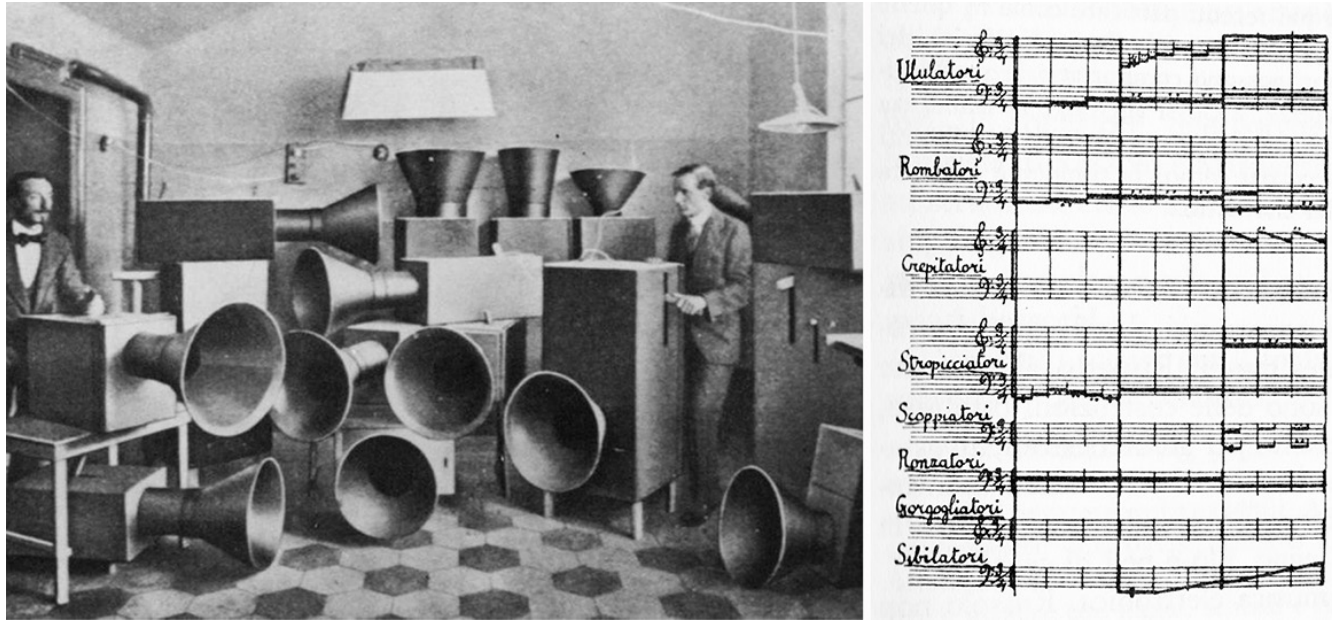
Fig. 2. a) Bruno Maderna, partitura, 1970: b) León Schidlowsky DADAYAmaSchidlowsky, DADAYAmaSONG, partitura, 1975 Sylvano Bussottl, Piano plece for David Tudor Sylvano Bussotti, Siciliano Sylvano Bussotti, Sic partitura, 1962
Pittore accademico (da giovane era stato collaboratore del restauratore Crivelli al Castello Sforzesco e al Cenacolo di Leonardo), fu in ambito musicale che si distinse, accogliendo quelle inquietudini già manifestate da Ferruccio Busoni riguardo ai freni imposti alla produzione musicale contemporanea dai limiti degli strumenti tradizionali [Busoni 1906].

Con il suo 'intonarumori', Russolo ha chiaro che l'obiettivo non era quello di raggiungere "un ritratto della tecnica, una programmatica armonia imitativa. [...] Egli impiegò sempre in modo stilizzato il nuovo materiale acustico - sciolto dal suo significato esteriore - come simbolo di un nuovo sentimento vitale, come brutale, battagliero urlo primitivo" [Prieberg 1963, p. 30].
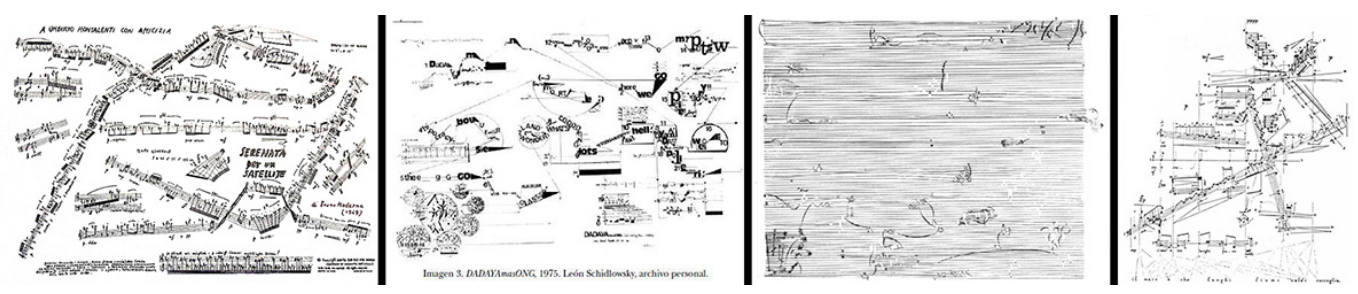

Se il primo posto di strumento elettrico può essere sicuramente ascritto all'intonarumori, per quanto già in America si conducessero esperimenti di elettrofonogenesi, nel giro di pochi anni la comparsa del theremin avrebbe determinato la nascita del primo strumento che non prevedesse il contatto fisico con l'esecutore.

La natura di questi, ma anche di altri strumenti elettronici che si susseguono con rapidità, introducono il concetto di "alea" nell'esecuzione musicale (Boulez 1957, p. 27; Lanza I983, p. 59). Non ci si riferisce tanto all'incertezza del risultato dell'esecuzione che, essendo frutto di una prestazione estemporanea, può dare adito a incontrollabili e indesiderati risultati discordanti da quanto prescritto nelle intenzioni del compositore (e comunque non potrà dare adito a due esecuzioni identiche) quanto, al contrario, a un processo che prevede una "imprevedibilità controllata', ossia uno o interi momenti in partitura in cui l'autore preordina e prescrive la casualità assoluta (o controllata entro un range) dell'esecuzione (fig. 3).
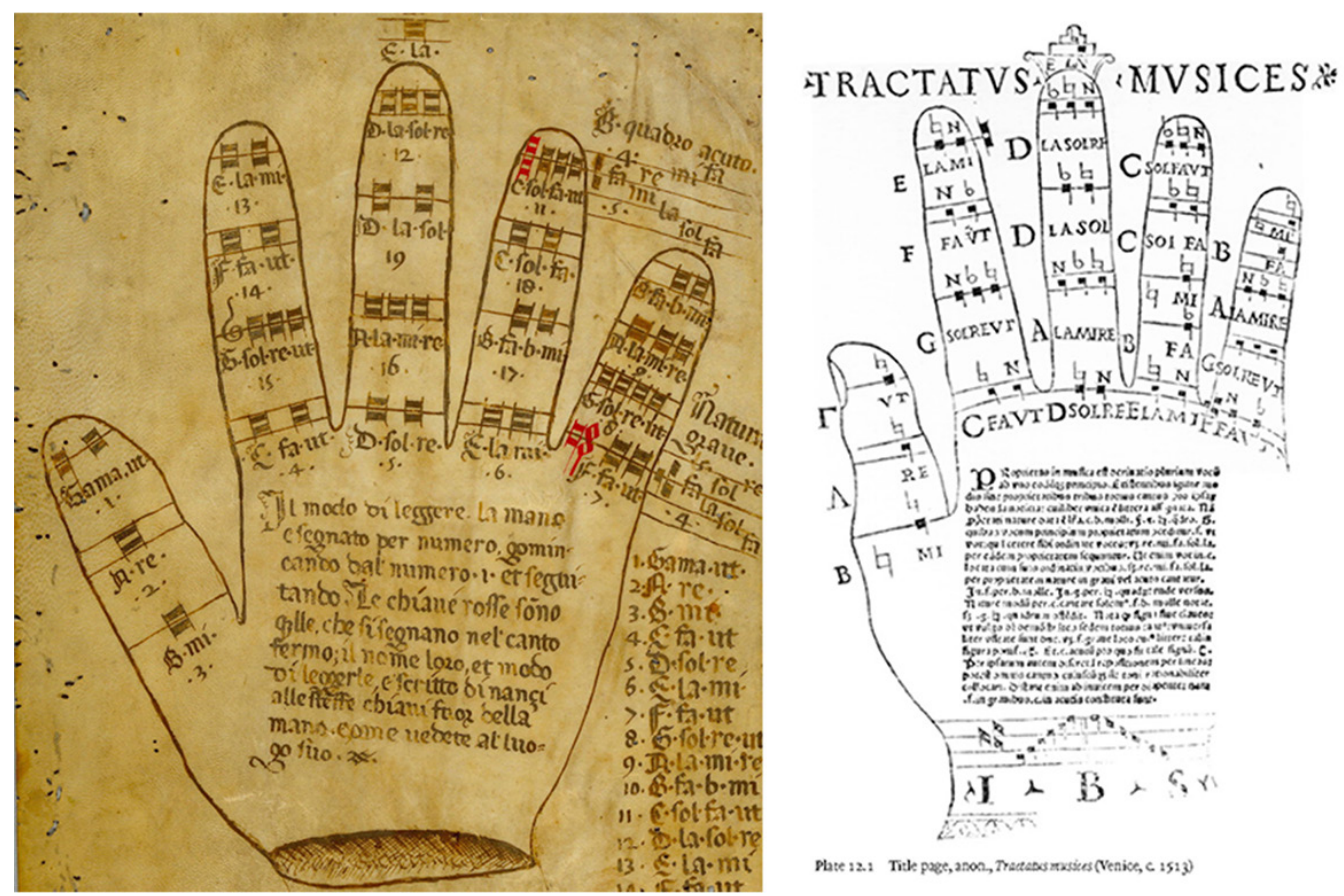
Fig. 4. a) Enore Zaffiri, Progetto EL/25: ellisse, par titura, 1968; b) Gottfried Koenig, Essay, partitura, 1958.
Nel momento della sua istituzionalizzazione, tale procedimento, per la verità già approcciato ludicamente dai compositori sin dal '700 (si pensi al cospicuo numero di "giochi a dadi musicali"), necessita presto un aggiornamento delle modalità della notazione musicale.

Da questa necessità si dipanano due questioni abbastanza cogenti.

I) Per quanto i compositori tentino di accomunare i nuovi strumenti in 'famiglie' (lo stesso Russolo parla di stropicciatori, ululatori, scoppiatori, sibilatori, rombatori, etc), in verità ogni nuovo strumento e soprattutto ogni nuovo procedimento inventato dall'autore, necessita un sistema notazionale autonomo, inventato per l'occasione (fig. Ib).

La partitura, ma soprattutto il suo codice segnico, diventa pertanto un unicum, mentre in virtù dell'evento aleatorio, non altrettanto si può affermare per la sua esecuzione, essendo sempre imprevedibile. La stessa partitura assume pertanto anche un valore figurativo che tenta di esplicare le modalità esecutive, generando un'anticipazione sinestesica e assumendo in sé un valore quasi fisiognomico rispetto non solo all'esecuzione, ma anche allo spazio in cui l'esecuzione ha luogo, dal momento anche che il più delle volte è prevista la dislocazione degli esecutori in più punti non convenzionali dello spazio teatrale [Ferrero 197I, p. 17].

2) La frattura che si crea nella rispondenza tra edificio teatrale, esecuzione musicale e notazione.
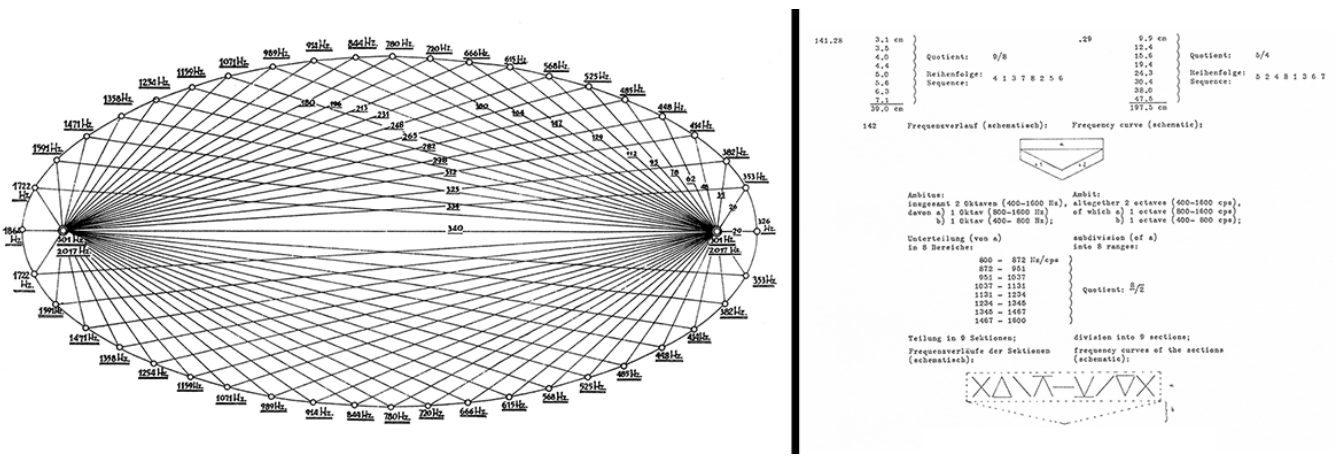

Questo rapporto, storicamente molto consolidato, si è sempre incentrato sulla trivalenza dell'accezione della parola 'teatro', inteso come testo letterario, come drammaturgia e infine come edificio [Centineo 2006, pp. I5- 17; Centineo 2007, pp. I35- | 40].

Nell'antica Grecia, ad esempio, tale corrispondenza è evidente nella messa in scena della tragedia. Ad esempio, 'parodos' esprime al contempo un momento del testo tragico, l'entrata scenica del coro e una parte dell'edificio teatrale, tre elementi in stretta relazione fra loro. Con l'introduzione dell'arco scenico nell'edificio teatrale, Monteverdi sottolinea nella partitura de L'Orfeo la relazione precisa tra azione e architettura: "Toccata che si suona avanti il levar de la tela", dicitura che esprime la specularità dell'azione scenica rispetto alla realtà oggettiva, sottolineata da un personaggio attante (la Musica ne L'Orfeo, ma anche Ovidio ne La Dafne di Marco da Gagliano), che pone in relazione la realtà del racconto con l'immaginario raccontato.

Con l'avvento della musica elettronica e della sua notazione avviene un cambio epocale. In particolare dallo sviluppo della musica prodotta tecnologicamente emerge anche la necessità di un nuovo codice notazionale, che, almeno all'inizio, sembra concentrarsi maggiormente a fissare ideologicamente sulla partitura le intenzioni dell'autore, piuttosto che curarsi dell'esecuzione o della riproducibilità del brano (figg. I b, 3).

II vecchio codice notazionale, quello consolidatosi dal Medioevo sino al Novecento, si basava su una corrispondenza figurativa di tipo cartesiano, in cui gli assi vengono sostituiti dal rigo musicale e l'origine stabilita dalla chiave: in ordinate l'altezza della frequenza del suono viene espressa dal posizionamento in altezza della nota sul pentagramma; in ascisse invece viene espresso lo scorrimento in senso diacronico, con variazioni agogiche e dinamiche. 
Da questo ordinamento convenzionale scaturisce un linguaggio e, come conseguenza, una diegesi, in cui il ruolo della mnemotecnica è cardinale.

La mano guidoniana era stata la dimostrazione più ingenua, ma al tempo stesso sintomatica, della rispondenza mnemonica tra esecutore e notazione (fig. 2).

Nel secolo appena conclusosi invece, le nuove modalità della notazione musicale contemporanea, svincolandosi da un rapporto disciplinato con l'esecutore, generano una semantica inedita e assai complessa. Dalla difficoltà dell'esecuzione, intesa precedentemente nella sua accezione prestazionale, si passa ad una possibilità interpretativa resa ancor più complessa non solo dal ruolo e dallo sforzo richiesti all'esecutore, ma anche al fruitore.

Se lo scardinamento della grammatica musicale in un primo momento è fondamentalmente stilistico, ben presto genera un coacervo di questioni che lo stato dell'arte tenta di mettere a sistema [Gentilucci 1972].

Le tre tradizionali funzioni della notazione tradizionale (progettuale, normativa, analogico-descrittiva), espresse per pittogrammi, si estendono nella contemporanea a quattro: (fig. 4a) di progetto (ad uso esclusivo del compositore), (fig. 4b) di realizzazione operativa (per l'esecutore), (fig. 5a) di lettura (per l'ascoltatore/lettore) e una quarta che riunisce le precedenti (fig. 5b), generando una semantica inedita e complessa [Lanza 1983b, p. 363], in cui si avvincono tappeti sonori, nebulose timbriche, rarefazioni e addensamenti, spettri sonori, nuovi immaginari dimensionali, espressi per il tramite di ideogrammi.

Anche i tentativi di classificazione degli strumenti generatori di suoni costituiscono parte di questo tentativo ordinatore, benché la computer music vada oggi assai oltre e superi la questione [Ferrero 1971, p. 16]. Ma proprio per questo, al contempo emerge la questione dello spazio per la nuova musica, che, come dice Luciano Berio," "in un certo senso non esiste
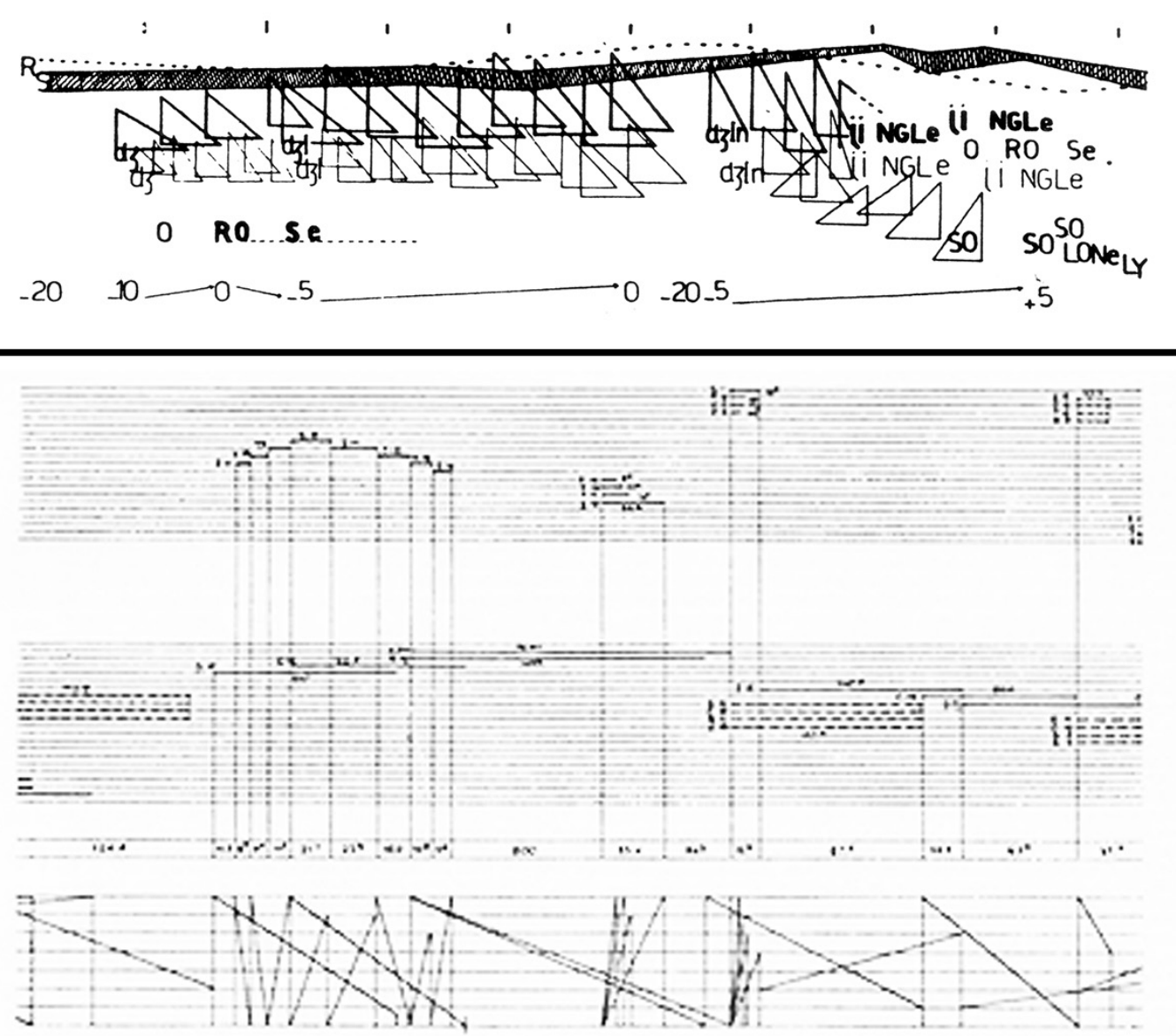
Fig. 6. a, b) lannis Xenakis, Edgar Varèse, partiture per Poéme Electronique (1958); c) lannis Xenakis, sviluppo tridimensioale di superfici rigate a partire dalla partitura; d) Le Corbusir con d) Le Corbusier con Philips, Bruxelles, 1958 più, perché è dappertutto e fa parte del pensare musicale di tutti i giorni" [Centineo 2006, p. 29; Pousseur 1976, p.Vl; Fugazza 1983, p. 263].

Lo stesso pensiero condivide Maurizio Sacripanti, quando nel 1964 assiste a un balletto con musiche di John Cage e scene di Robert Rauschenberg, in cui "lo spettacolo chiedeva gesti illimitati, ma il boccascena (della Fenice di Venezia, ndr) lo impediva" [Sacripanti 1973, p. 22]. II fatto che Sacripanti concepirà un 'teatro totale', espressamente basato sulle esigenze contemporanee, è solo la riprova di un nuovo tipo di rapporto che si instaura tra la nuova musica e quella che avrebbe dovuto essere una nuova architettura.
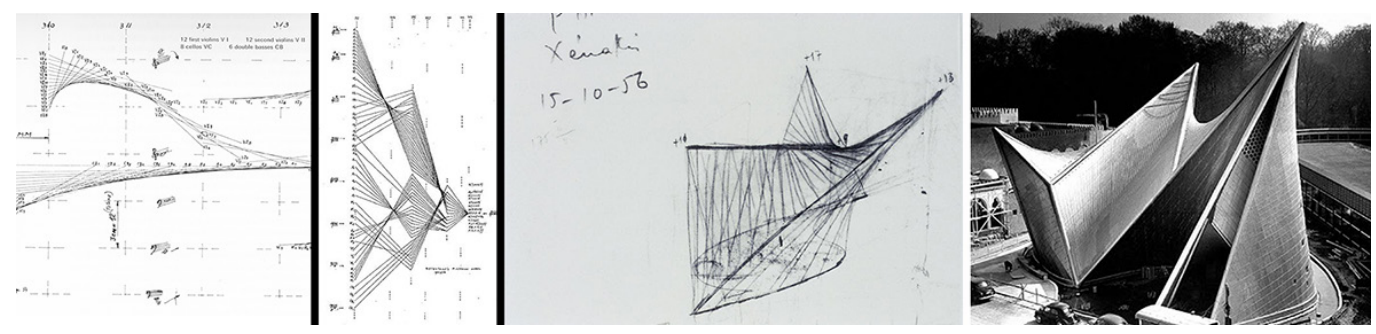

Per i motivi sopra espressi, in particolare per la varietà del panorama musicale e teatrale, l'approccio di tipo funzionalistico, che potrebbe sembrare il più ovvio, essendo radicato in aspetti concreti dell'edificio teatrale, si rivela un orizzonte utopistico. Alcune esperienze anteguerra avevano già intrapreso questo cammino di rinnovamento. Per citarne alcune, si pensi al Theatre n. 14 di Norman Bel Geddes (1922), al Kugeltheater di Andor Weininger ( 1924), al coevo Endlosen Theater di Frederyk Kiesler, esperimenti che culminano nel Total Theater che Walter Gropius progetta per Erwin Piscator nel 1927.

Dal dopoguerra altresì inizia a manifestarsi una corrispondenza inedita tra il tentativo di individuare un edificio teatrale moderno e la semantica delle partiture contemporanee che si potrebbe definire di tipo fisiognomico inverso. Questo sentiero individua cioè nelle partiture contemporanee quel carattere figurativo di tipo spaziale, che molto spesso i compositori trasfondono nelle loro opere, avendo avuto la grande intuizione di legare insieme tempo e spazio, non solo nella loro dimensione di parametro fisico (si pensi alla coincidenza filosofica con la relatività einsteiniana), ma anche corporea ed estetica.
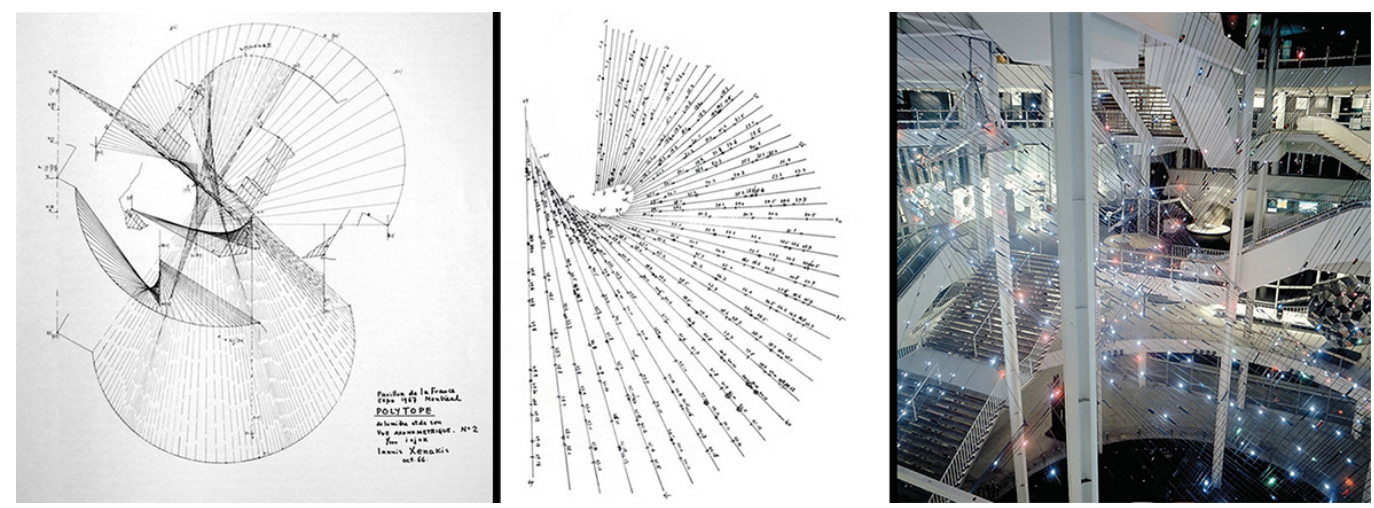

Le Corbusier, con il cospicuo contributo di lannis Xenakis, progetta il Padiglione Philips, non solo con un programma funzionale ben chiaro, ma trasformando formalmente i diagrammi delle partiture che l'architetto e compositore greco sta sperimentando in superfici rigate, all'interno delle quali nel 1958 risuonerà il Poème Electronique di Edgar Varèse (fig. 6). Dal 
Fig. 8. a) lannis Xenakis, Hibiki Hana Ma, partitura, 1970; b) Earle Brown, December 1952, partitura, 1952; c) Maurizio Sacripanti, pianta del livello della platea del progetto per il teatro Lirico di Cagliari, 1964.
Fig. 9. a, b) Jacques Polièri, Enzo Venturelli, Thèatre du Mouvement Total, 1963; c) Josef Svoboda, progetto di teatro polivalente per Praga (fine anni'60).
1967 al 1978 ininterrottamente Xenakis sperimenterà i suoi Polytope (fig. 7), concezioni spaziali sinestesiche di spazio, suono e luce [Xenakis 2006], anticipando razionalmente certi esiti dionisiaci che i primi epocali concerti di gruppi quali i Rockets, i Kraftwerk, i Tangerine Dreams, senza contare i Pink Floyd e Brian Eno, avrebbero scritto nella storia dello spettacolo: dalle 1200 lampade che scintillavano a ritmi e frequenze algoritmiche nel Polytope di Montreal del 1967, all'utilizzo dei primi raggi laser nel Polytope de Cluny (Parigi, 1972), non prima di passare per il tappeto sonoro di Hibiki Hana Ma, registrato all'Esposizione di Osaka del 1970, quella stessa Expo per cui Maurizio Sacripanti avrebbe progettato il Padiglione Italiano, una visionaria architettura in movimento.
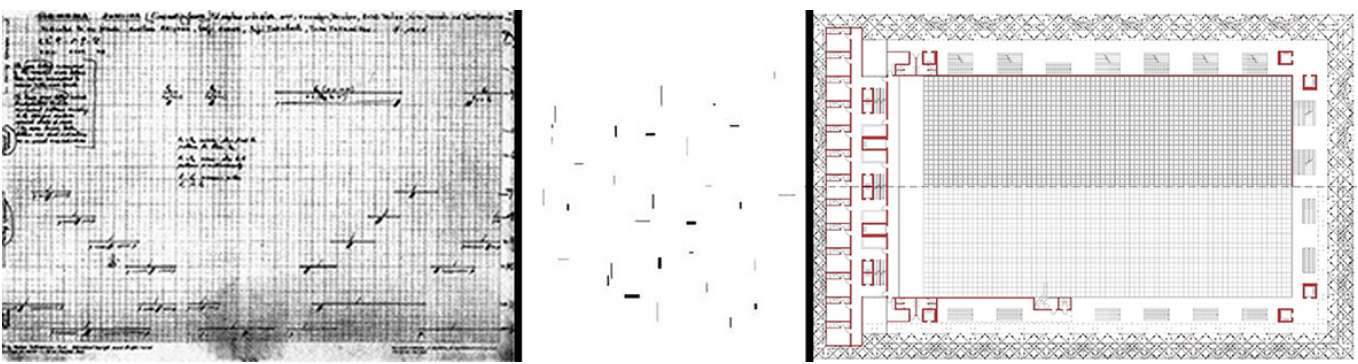

Proprio alla partitura di Hibiki Hana Ma (fig. 8a) sembra avvicinarsi il tentativo più razionale e al contempo fisiognomico di Sacripanti, il progetto per il Teatro Lirico di Cagliari del 1964 (fig. 8c), un cangiante tappeto, paragonabile alle configurazioni di Earle Brown (fig. 8b) o di Sylvano Bussotti (fig. 3c): un continuum spazio-sonoro, predisposto per accogliere qualsivoglia gesto progettuale in una sorta di libertà controllata che ricorda sulla carta il nitore miesiano, interprete peraltro anch'egli di un teatro sperimentale per Mannheim (1952), ma anche i procedimenti aleatori di cui si diceva sopra.

Due registi protagonisti del Novecento teatrale, Josef Svoboda e Jacques Polièri, oltre a numerosi spettacoli, non mancano di progettare spazi scenici, secondo una logica che oggi chiameremmo 'concept'. Teatri centrici, quale il Thèatre du Mouvement Total (figg. 9a, 9b) che Enzo Venturelli progetta per Polièri nel 1963 (analogamente a quanto Gropius aveva
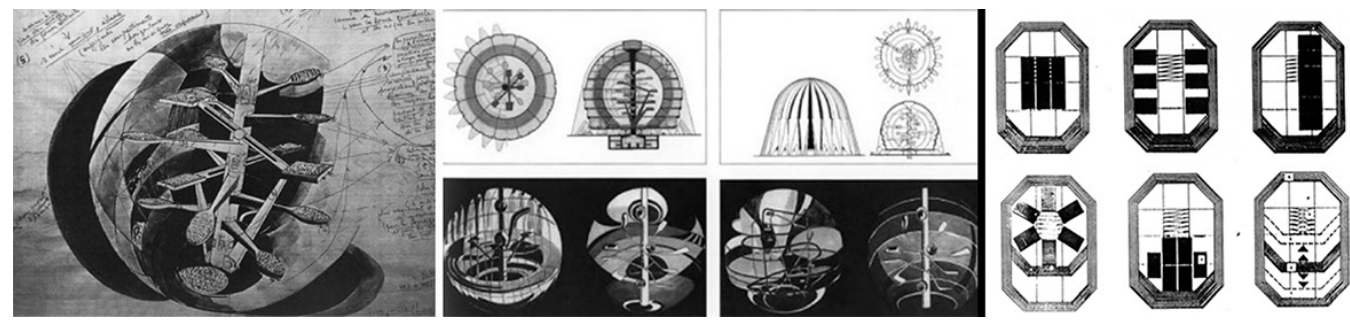

fatto per Piscator), o cangianti, quale quello che Svoboda (fig. 9c) ipotizza per Praga alla fine degli anni '60 (Svoboda 1989), che anticipano certe partiture che Pierre Boulez a metà degli anni ' 80 avrebbe perfezionato in carnet di indicazioni non solo musicali (fig. I0), ma anche spaziali, come in Dialogue de l'ombre double (1985).

Tale contributo risulta decisivo per il progetto della sala dell'IRCAM di Parigi, progettata da Renzo Piano e Richard Rogers, espressamente per Pierre Boulez e il suo Ensemble Intercontemporain.

Approccio iperdeterministico, radicalmente opposto alle cellule del progetto di auditorium per Gent di Andrea Branzi e Toyo Ito, una 'spugna sonora' che mostra straordinarie analogie 
Fig. 10. Pierre Boulez, due pagine dal carnet di Dialogue de l'ombre double, 1984.
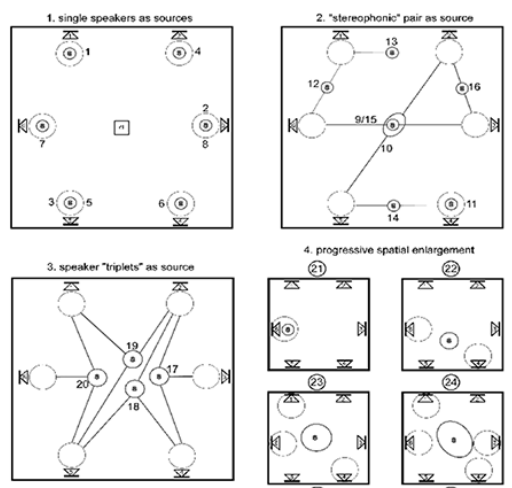

KEY:
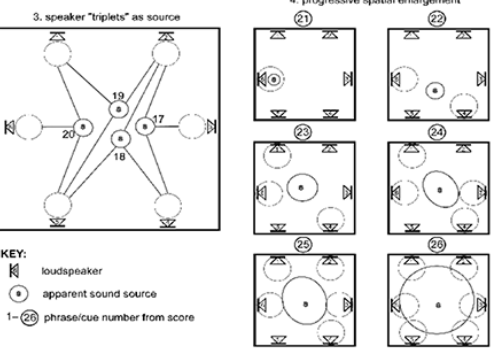

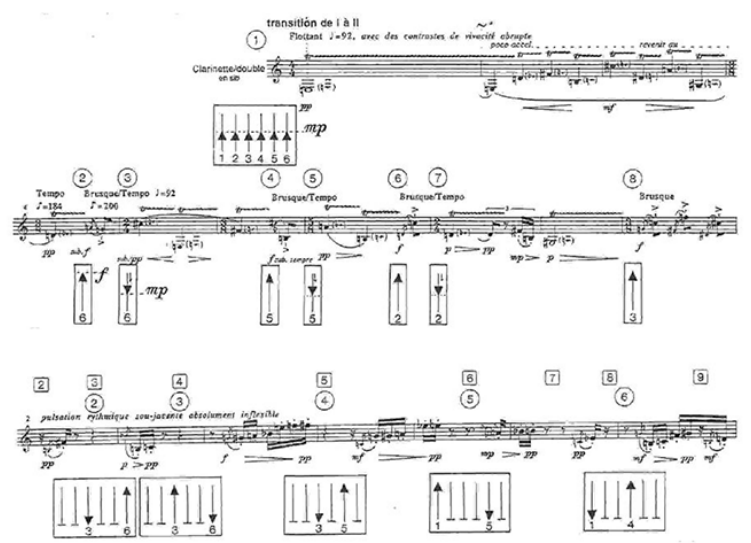

(fig. I I) con gli ammassi globulari di talune partiture di Mauricio Kagel (Transición II del 1958), o di Karlheinz Stockhausen (Zyklus del 1959).

Del resto, lo stesso Stockhausen, scopritore del 'suono bianco' (analogo acustico del fenomeno visivo della sindrome additiva della luce), in Tunnel Spiral del 1969, altro non riecheggia se non le forme ancestrali del Thersilion ipostilo di Megalopoli (IV sec. a. C.) (fig. I2).

Un percorso dunque che procede per incarnazioni successive in cui notazione e architettura si progettano e si annotano reciprocamente. Architetture, tutte quelle cui si è fatto riferimento, quasi sempre rimaste sulla carta, ma ascrivibili al mondo delle Idee, esattamente come quell'impalpabile musica a cui si è fatto riferimento continuo, che esiste e si rivolge all'uomo, pur restando intangibile.

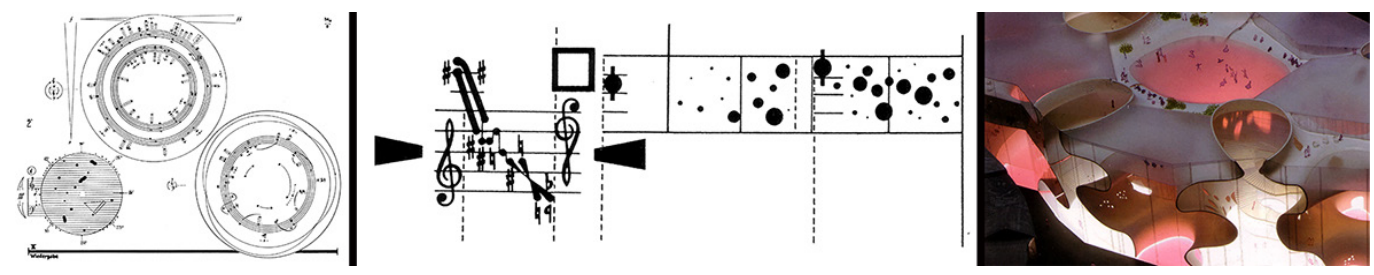

Annota Xenakis:"L'artista gioca con le forme proprio come lo scienziato o il credente. II musicista lo fa in modo ancor più sistematico, poiché vive simultaneamente nel microcosmo del suono e nel macrocosmo delle architetture più vaste, come se si trovasse in una millefoglie fatta di strati trasparenti in tutti i sensi" [Pierangeli 2015].
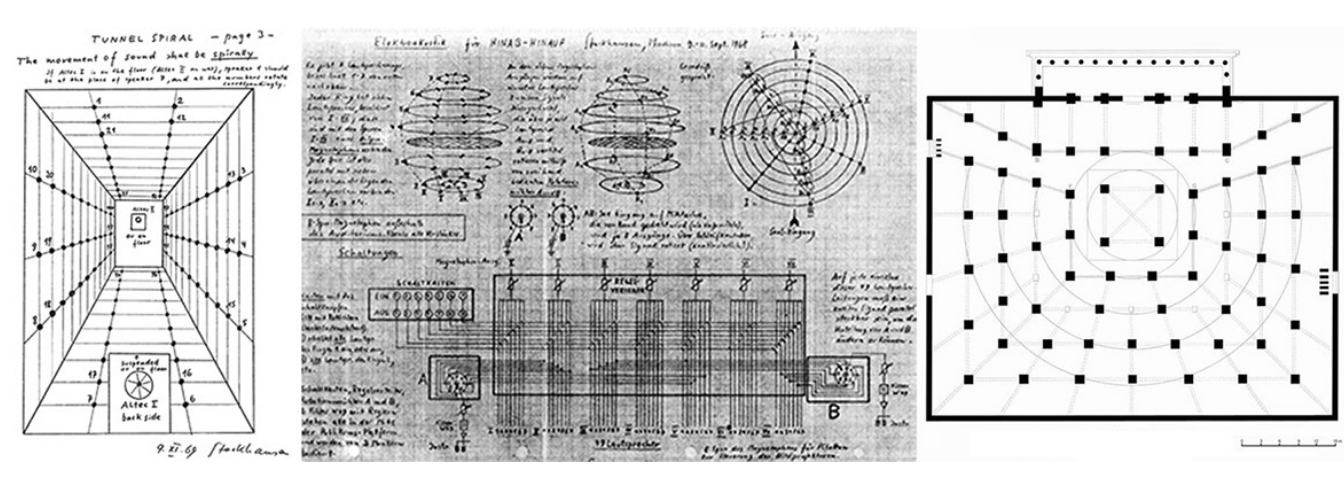
Stockhausen, Tunnel applicazione di Tunnel Spiral alla pianta circolar dell'Expo di Osaka; c) Megalopoli, pianta del Thersilion
sec. a. C.).
Fig. 12. a) Karlheinz b) Karlheinz Stockhausen,

Kagel, Transición II, partitura, 1958; b) Karlheinz

partitura, 1959; c) Andre del progetto, plastico

per l'Auditorium di Gent 


\section{Riferimenti bibliografici}

Boulez Pierre (1957). Alea. In La Nouvelle Revue Française, n. 59, pp. 25-29.

Busoni Ferruccio (1906). Entwurf einer neuen Ästhetik der Tonkunst. Leipzig: Zweite, erweiterte Ausgabe.

Centineo Santi (2006). Representamen. II ruolo dell'Architettura degli Interni nel ripensamento del rapporto musicalarchitettural società. Dottorato di Ricerca in Architettura degli Interni e Allestimento, Politecnico di Milano, XX Ciclo. Tutor: prof. Andrea Branzi.

Centineo Santi (2007). Cave caveam. In Branzi Andrea, Chalmers Alessandra (a cura di). Spazi della cultura, cultura degli spazi. Nuovi luoghi di produzione e consumo della cultura contemporanea. Milano: FrancoAngeli, pp. I33- I 48.

Ferrero Lorenzo ( I97| ). La fabbrica dei suoni. In Pianeta, n. 43, pp. I I-2 I.

Fugazza Gian Felice (1983). Elettronica, Musica (ad vocem). In DEUMM (Dizionario Enciclopedico Universale della Musica e dei musicisti), vol. IV,Torino: UTET, pp. 256-278.

Gentilucci Armando (1972). Introduzione alla musica elettronica. Milano: Feltrinelli, pp. 128.

Lanza Andrea (1983). Alea (ad vocem). In DEUMM (Dizionario Enciclopedico Universale della Musica e dei musicisti), vol. I, Torino: UTET pp. 59-60

Lanza Andrea (1983). Notazione (ad vocem). In DEUMM (Dizionario Enciclopedico Universale della Musica e dei musicisti), vol. IX, Torino: UTET, pp. 338-367.

Pierangeli Fabio (20I5). lannis Xenakis. La legende d'Eer. <https://www.ondarock.it/speciali/iannisxenakis_lalegendeder.htm>.

Pousseur Henri (1976). La musica elettronica. Milano: Feltrinelli.

Prieberg Fred K. (1963). Musica ex machina.Torino: Einaudi. (I Ed. (1960). Musica ex machina. Über das Verhältnis von Musik und Technik. Berlin-Frankfurt-Wien:Verlag Ullstein.

Sacripanti Maurizio (1973). Città di frontiera. Roma: Bulzoni

Svoboda Josef (1989). Architetture dellimmaginario. Milano: Ubulibri.

Xenakis lannis (2006). Musique de l'architecture. textes, réalisations et projects architectureaux choisis, présentés et commentés par Sharon Kanach. Marseille: Éditions Parenthèses.

\section{Autore}

Santi Centineo, Politecnico di Bari, santi.centineo@poliba.it

Per citare questo capitolo: Centineo Santi (2020). Archi-partiture. Sperimentazioni e corrispondenze fisiognomiche tra notazione musicale e architettura teatrale nel '900/Archi-scores: physical experimentation and correspondence between contemporary musical notation and theatre architecture. In Arena A., Arena M., Brandolino R.G., Colistra D., Ginex G., Mediati D., Nucifora S., Raffa P. (a cura di). Connettere. Un disegno per annodare e tessere. Atti del $42^{\circ}$ Convegno Internazionale dei Docenti delle Discipline della Rappresentazione/Connecting. Drawing for weaving relationships. Proceedings of the 42th International Conference of Representation Disciplines Teachers. Milano: FrancoAngeli, pp. 1045 - 1062 


\title{
Archi-Scores. Physical Experimentation and Correspondence between Contemporary Musical Notation and Theatre Architecture
}

\author{
Santi Centineo
}

\section{Abstract}

The paper aims to examine the relationship between musical notation, as it evolves in the musical scores of the second half of the twentieth century (in particular electronic and aleatory music) and architecture design, to be concerned as a container for listening, finding in this process a physiognomic nature of conformity.

The research is corroborated by the theoretical writings of composers who since the 50 s have tried to justify their own research, at the same time offering an autoptic documentary picture.

Study of musical scores of the twentieth century and comparison with spaces for music of the second half of the twentieth century.

Recognition of a reciprocity between musical notation and architecture, in which the common denominator is representation, which, through contemporary scores, attempts to combine musical anticipation with spatial prefiguration, in a kind of theoretically relevant synesthesia, as it abandons the sensorial and aesthetic results for the benefit of the theoretical and conceptual ones.

Keywords

musical notation, musical space, prefiguration, synesthesia.

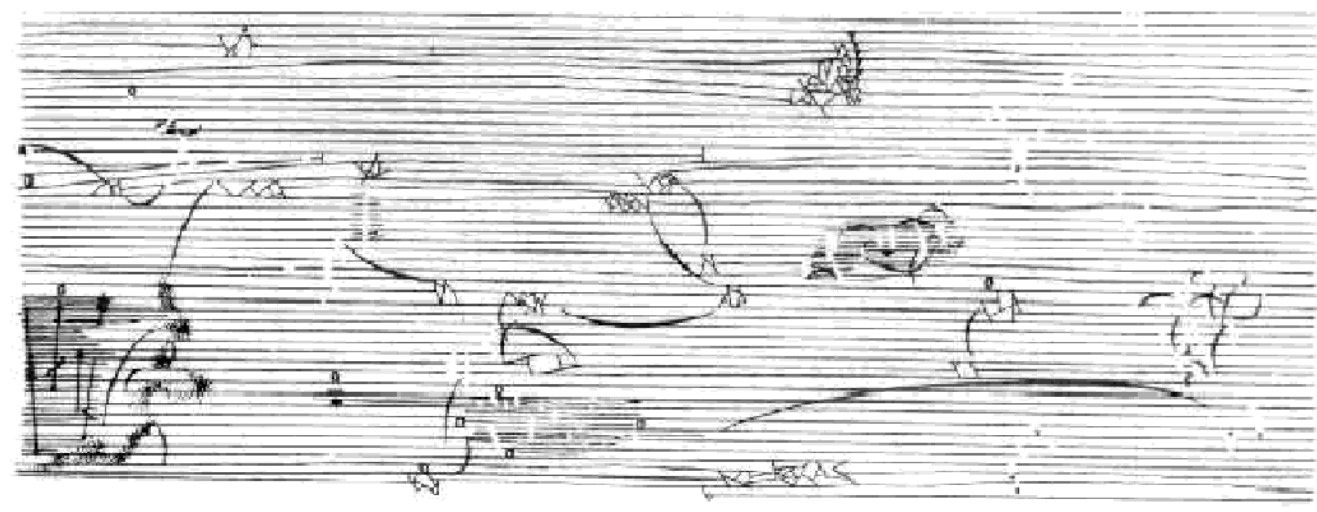


In all areas (for example, literature, music or architecture), where there is an evident relationship between the narration, that is to say the idea-telling, and its formal concretization, finds a crucial moment of linking in the possibility of its notation.

The notation itself conventionally finds some sign elements, an own alphabet, through whose shared ordering springs a language and, as a consequence, a diegesis: the alphabet (in the written language, finding its fulfilment in reading), the graphic representation (in architecture, prefiguring and ruling the construction), and the notational system (in the case of music, preluding to the instrumental execution).

In all three cases, either regardless of the formal realization of the represented idea, or accessing it, the resulting process, intersubjective in nature, starts from the standard objectivity of the code, and extends to its interpretative possibilities, which are disemboweled in the benefit of mass reproducibility. But, while in the case of allographic arts (photography, graphics, cinema or design) the serial process generates identical specimens to the original, in the three cases mentioned above, the completion process takes place through the interpretative magisterium, which will never allow the identical of two specimens.

At the end of the Nineteenth Century, romantic music, like many other arts, progressively enters into crisis. Not only does the ideology of romanticism begin to turn out to be progressively unsuccessful, but all the arts begin to wonder how to accompany, refuse or oppose industrial development, which inevitably aims to intersect its own destiny with them. The Great International Exhibitions (starting from the Parisian Exhibitions, to culminate with the London Exhibition of I85 I) fully expressed that positivism that often did not struggle to degenerate into a kind of salvific exaltation of progress, also starting a process of aesthetic research, to legitimise and double bind the arts and the industry.

The music had not failed to attest with its presence the importance of some of these moments, indeed it had contributed in some way to confirm their legitimacy. Hector Berlioz repeatedly conducts orchestras of unusual organic (over a thousand performers) in industrial buildings, such as the Crystal Palace, showing the use of the modern electric metronome, furthermore using innovative instruments (saxophone, for instance) or last generation ones (the harmoniums).

It is the beginning of a path of commercialization and objectification of the artistic path, that would shortly lead to a rift which could not be healed, perhaps impossible, between the materiality of musical production contexts and the immateriality of music itself.

The noises of the modern world, coming from the industries, from the machines, from the new excitement, from new objects and materials, quickly change the scenery and the sonorous landscape, before of this process intended as a consequence of the imitative nature, still always inherent in the music.

When in June 1913 Luigi Russolo presented his 'intonarumori' (noise-intoner), at the Teatro Storchi in Modena, there was a sensation announced (fig. Ia).

Fig. I. a) Luigi Russolo presents his 'intonarumori' with his assistent, Ugo Piatti (1913); b) Luig Russolo, Risveglio della città for 'intonarumori', full score (19/3).
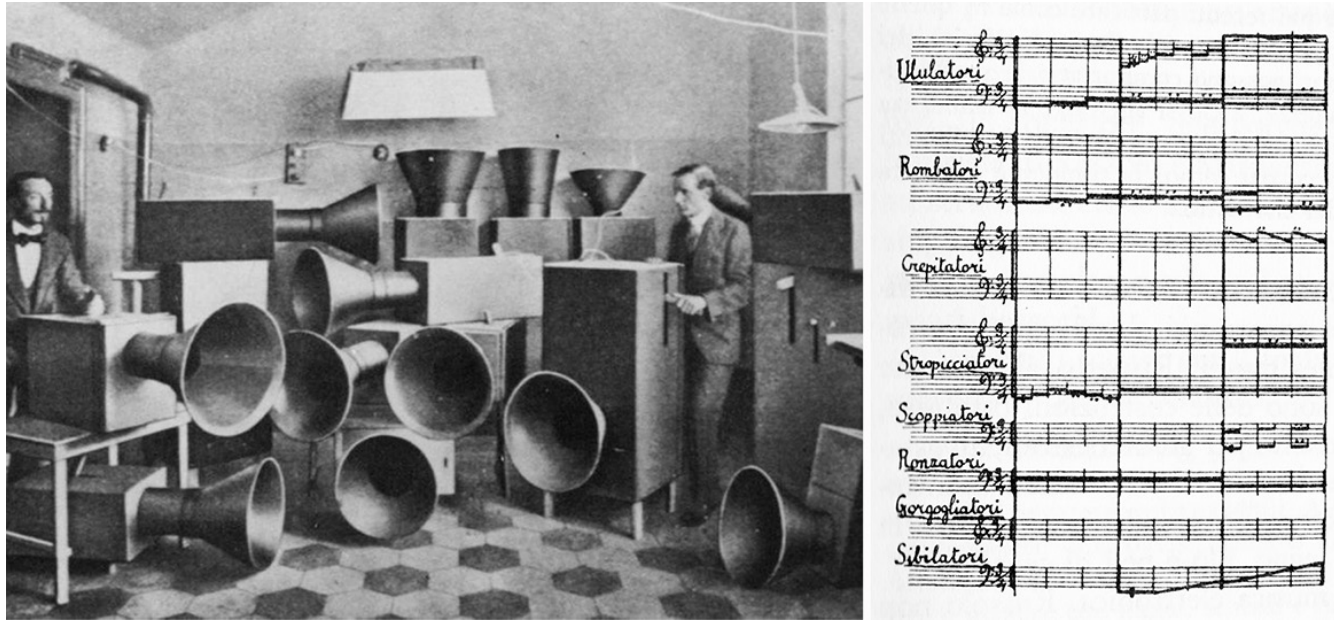
Fig. 2. a) Bruno Maderna, full score, 1970: b) León Schidlowsky, DADAYAmo Schidlowsky, DADAYAmasONG, full score, 1975; c Sylvano Bussotti, Piano piece for David Tudor Syll score, 1970 ; d) Sylvano Bussotti, Siciliano, full score, 1962
Fig. 3. a) The 'Guidonian Hand"'in a Middle-Age document; b) and in the Tractatus Musices by Anonimous, 1513 .
Academic painter (when he was a young collaborator of the restorer in the Sforza Castle and the Leonardo's Last Supper), was in the musical field that stood out, accepting those concerns already expressed by Ferruccio Busoni about the brakes imposed on contemporary musical production by the limits of traditional instruments (Busoni 1906).

With his 'intonarumori', Russolo made it clear that the goal was not to achieve "a portrait of the technique, a programmatic imitative harmony. [...] He always employed in a stylized way the new acoustic material - dissolved by its external meaning - as a symbol of a new vital feeling, as a brutal, combative 'primitive scream'” [Prieberg 1963, p. 30].
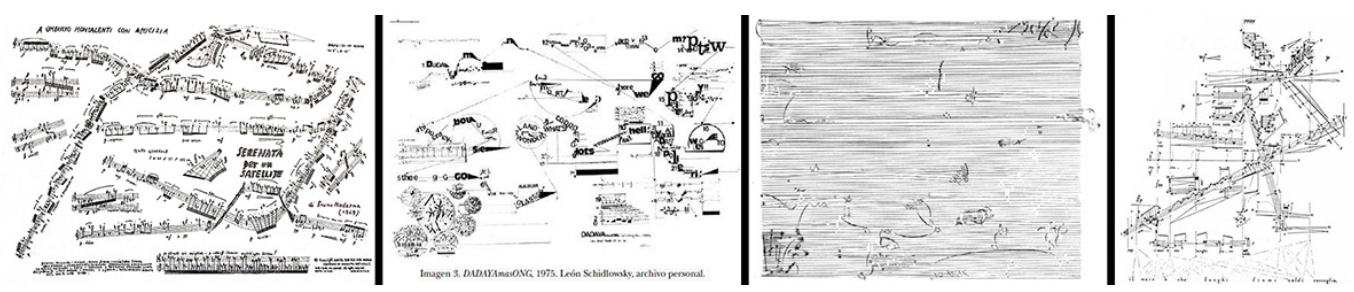

If the 'intonarumori' can surely be considered the first electric instrument, although in America experiments of electrophonogenesis were already conducted, within a few years the appearance of the theremin would have led to the birth of the first instrument that did not foresee any physical contact with the performer.

The nature of these, but also of other electronic instruments that follow each other with rapidity, introduces the concept of 'alea' in musical execution.

We do not refer so much to the uncertainty of the result of the execution that, being the result of an extemporaneous performance, can give rise to uncontrollable and unwanted results divergent from what is prescribed in the intentions of the composer (and in any case cannot give rise to two identical executions) but, on the contrary, to a process that provides for a controlled 'unpredictability', to one or whole moments in the score, in which the author orders and prescribes absolute (or controlled within a range) randomness of the execution itself (fig. 2).
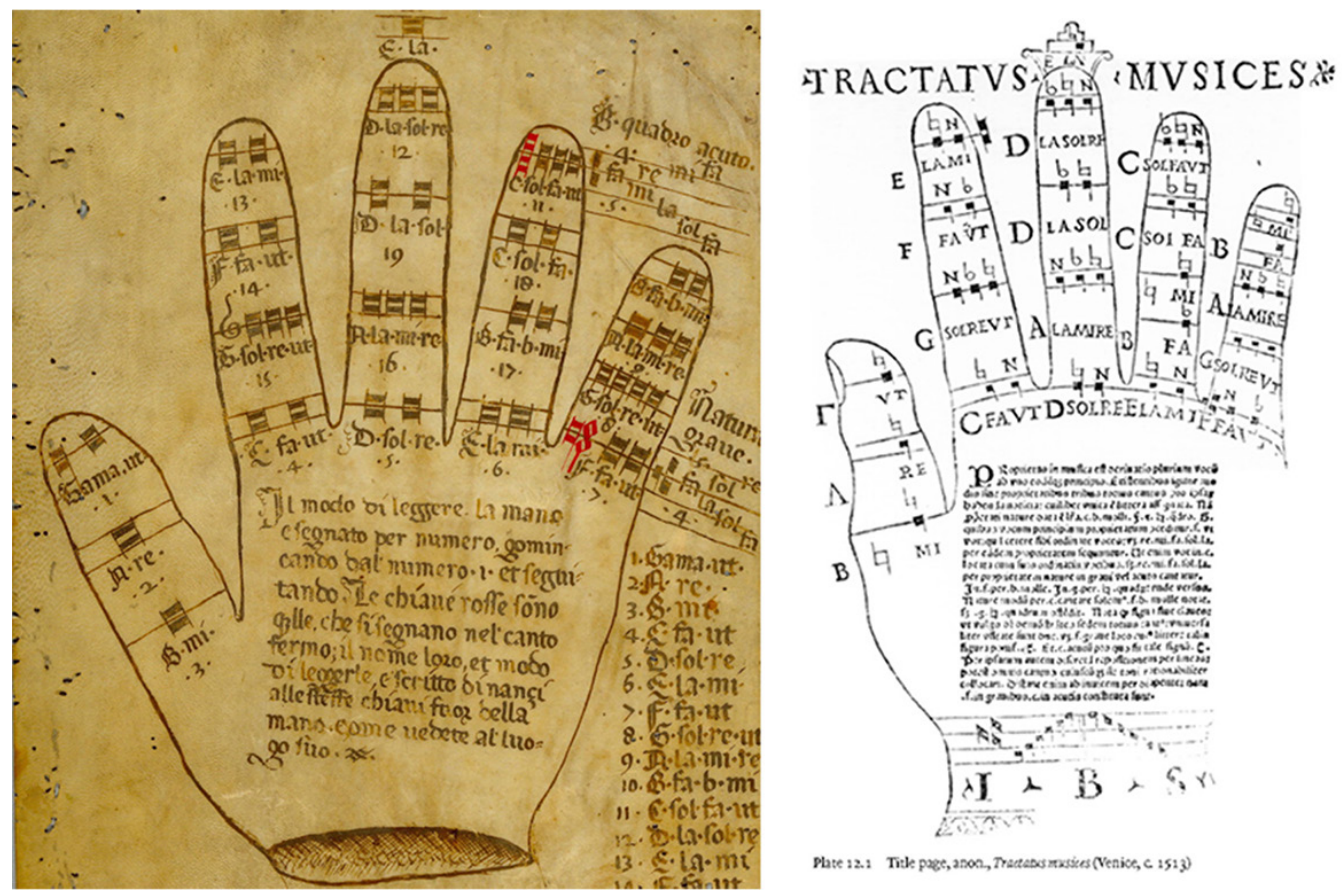

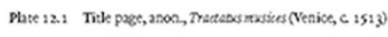


Fig. 4. a) Enore Zaffiri, Progetto EL/25: ellisse, full score, 1968; b) Gottfried Koenig, Essay, full score, 1958.
At the moment of its institutionalization, this procedure, already playfully approached by composers since the '700 (think of the conspicuous number of 'dice musical games'), needs soon the modalities of musical notation to be updated.

Two pretty cogent questions arise from this need.

I) As much as the composers try to combine the new instruments in 'families' (Russolo himself speaks of 'throttlers', 'ululators', 'bursters', 'sibilators', 'rhombulators' etc.), actually every new instrument, and especially every new procedure invented by the author, requires an autonomous notational system, invented for the occasion (fig. Ib).

The score, but above all its segnic code, thus becomes an unicum, while, thanks to the random event, not so much can be said for its execution, being always unpredictable.

Therefore, the score itself also assumes a figurative value that tries to explain the executive modalities, generating a synesthetic anticipation and assuming in itself an almost physiognomic value, with respect not only to the execution, but also to the space in which the execution takes place, since most of the times the performers are planned to be dislocated in several unconventional points of the space.

2) The fracture that is created in the correspondence between theatrical building, musical performance and notation.
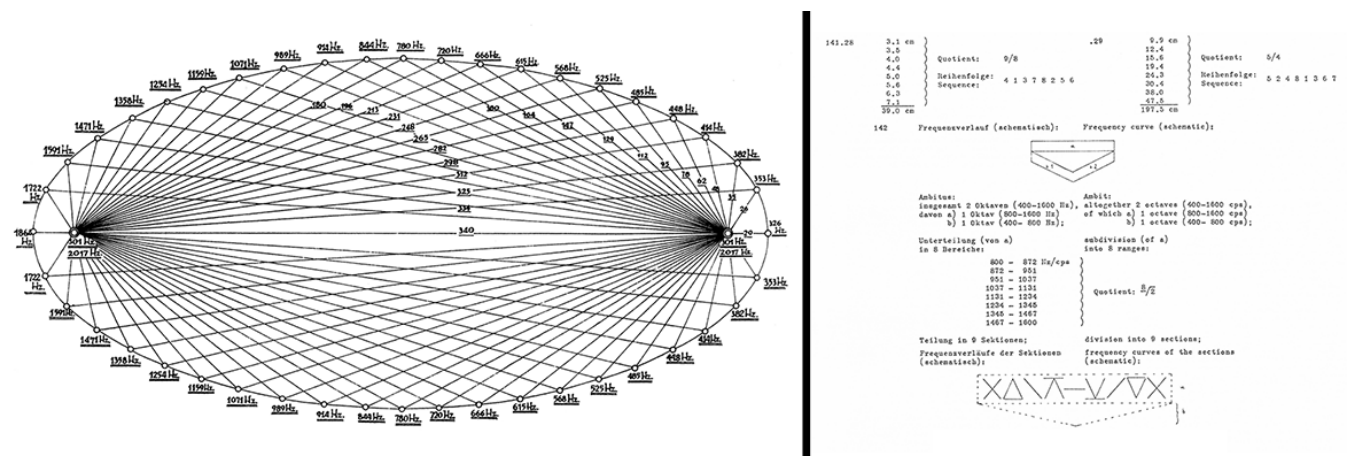

This relationship, historically very consolidated, was always focused on the trivalence of the meaning of the word 'theater', understood as literary text, as dramaturgy and finally as a building.

In ancient Greece, for example, such correspondence is evident in the staging of the tragedy. For example, 'parodos' expresses at the same time a moment in the tragic text, the scene entrance of the choir and a part of the theatre building, three parts in close relationship with each other.

With the introduction of the scenic arc in the theatrical building, Monteverdi emphasizes in the Toccata of L'Orfeo the exact relationship between action and architecture: "Toccata to be played ahead the curtain rising", that expresses the specularity of the stage action with respect to the objective reality, underlined by an actress (the Music in L'Orfeo, Ovidio in Marco da Gagliano's La Dafne) that relates the reality of the story with the imaginary story to be told.

With the advent of electronic music and its notation, an epochal change takes place.

In particular, the development of technological music also shows the need for a new notational code, which, at the beginning, seems to focus more on ideologically fixing on the score the intentions of the author, rather than caring about the execution or reproducibility of the piece (figs. Ib, 2).

The old notational code, that consolidated from the Middle Ages up to the Twentieth Century, was based on a figurative correspondence of Cartesian type, in which the axes are replaced by the musical staff and the origin established by the clef: in ordinates, the height of the frequency of the sound is expressed by the position in height of the note on the 
staff; in abscisse instead, the sliding in diachronic sense is expressed, with agogic and dynamic variations.

From this conventional order flows a language and, as a consequence, a diegesis, in which the role of mnemotechnic is cardinal.

The 'Guidonian hand' had been the naivest, but at the same time symptomatic, demonstration of the mnemonic correspondence between performer and notation (fig. 3).

In the century just ended, however, the new modalities of contemporary musical notation, freeing itself from a disciplined relationship with the performer, generate a new and very complex semantics. From the difficulty of execution, understood previously in its performance sense, we pass to an interpretative possibility, made even more complex not only by the role and effort required to the performer, but also to the user.

If the loosening of musical grammar is in a first moment fundamentally stylistic, it soon generates a host of issues that the state of the art tries to put into a system.

The three traditional functions of traditional notation (design, regulation, analogue-descriptive), extend in the contemporary to four: (fig. 4a) project (for the composer's exclusive use), (fig. 4b) operational realization (for the performer), (fig. 5a) reading (for the listener/reader) and a fourth that brings together the previous ones (fig. 5b), generating a new and complex semantics (Lanza 1983b, p. 363), in which sound carpets, nebulous timbres, rarefactions and sound thickening, sound spectra, and new dimensional imaginations take turns.

Attempts to classify sound-generating instruments are also part of this effort, although computer music today goes much further and beyond the question (Ferrero 1971, p. 16). But precisely for this reason, at the same time emerges the question of the space for the new music, which, as Luciano Berio says, "in a certain sense no longer exists, because it is
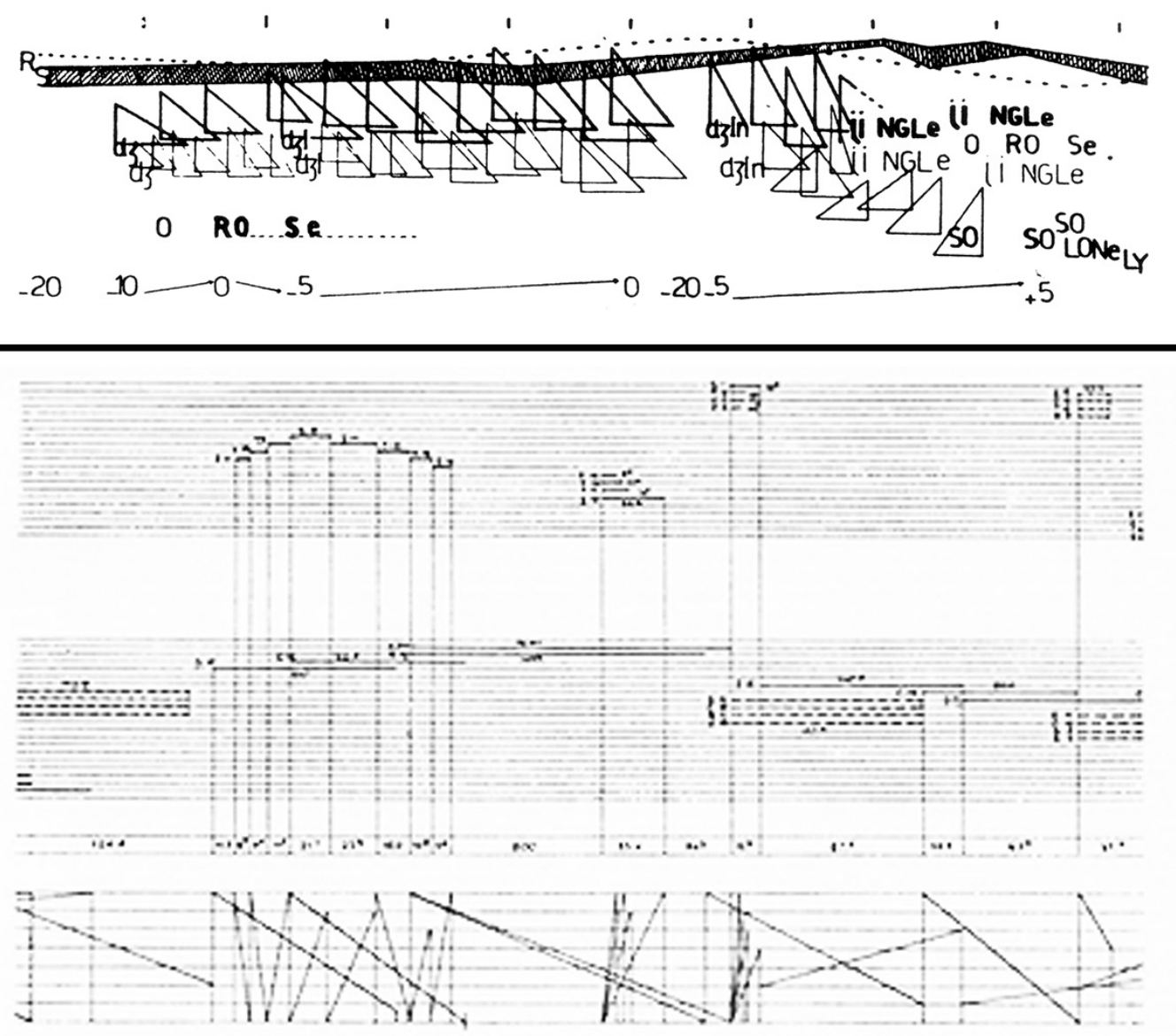
Fig. 6. a, b) lannis Xenakis, Edgar Varèse, scores (1958); c) lannis Xenakis, three-dimensional development of stripped surfaces, starting frome score (d) L Com the score, (d) Le Corbusier and lanis Xenakis, PadiPhilips, Bruxelles,

Fig. 7. a, b) lannis Xenakis, Polytope for Montreal Expo 1957; c) A picture of the French Pavillon at Montreal Expo with the installation of the Polytope, 1957. everywhere and is part of everyday musical thinking" (Centineo 2006, p. 29; Pousseur I976, p.Vl; Fugazza 1983, p. 263).

The same thought is shared by Maurizio Sacripanti, when in 1964 he attended a ballet with music by John Cage and scenes by Robert Rauschenberg, in which "the show demanded unlimited gestures, but the proscenium [of the Fenice of Venice, ed] prevented him" (Sacripanti 1973, p. 22).

The fact that Sacripanti will conceive a total theater", expressly based on contemporary needs, is the proof of a new type of relationship that it is possible to establish between the new music and what was supposed to be a new architecture.
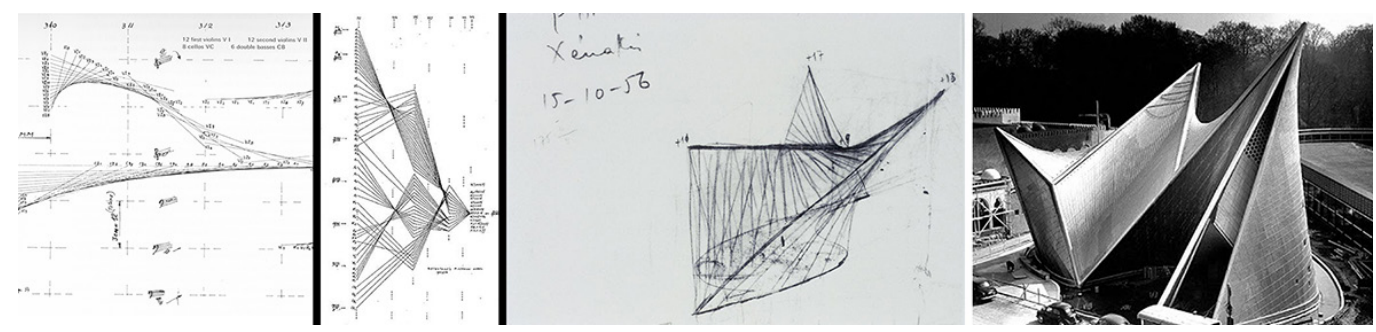

For the reasons expressed above, in particular for the variety of the musical and theatrical landscapes, the functionalist approach, which might seem the most obvious, being rooted in concrete aspects of the theatrical building, turns out to be a utopian horizon.

Some pre-war experiences had already embarked on this path of renewal. To quote some experiences, we think of the Theatre no. 14 by Norman Bel Geddes (1922), the Kugeltheater by Andor Weininger (1924), the coeval Endlosen Theater by Frederyk Kiesler, experiences that culminate in the Total Theater that Walter Gropius designed for Erwin Piscator in 1927. Since the post-war period, there has also been an unprecedented correspondence between the attempt to identify a modern theatre building and the semantics of contemporary scores, which could be defined as physiognomic (sometimes inverse). This path identifies in contemporary scores the figurative character of spatial type, which composers very often transmute in their works, having had the great intuition to link time and space together, not only in their physical parameter (think of the philosophical coincidence with Einsteinian relativity), but also corporeal and aesthetic.
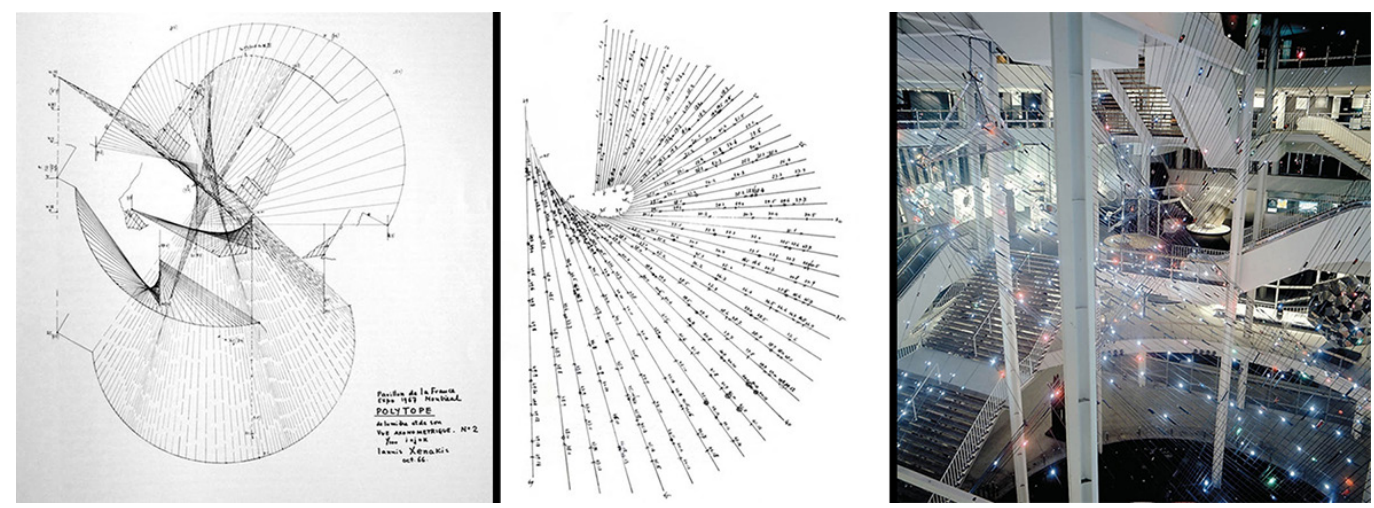

With the substantial contribution of lannis Xenakis, Le Corbusier designs the Philips Pavilion, not only with a clear functional program, but formally transforming the score diagrams, that the Greek architect and composer is experimenting with, into striped surfaces, within which in 1958 the Poème Electronique by Edgar Varèse will resound (fig. 6). From 1967 
Fig. 8. a) lannis Xenakis, Hibiki Hana Ma, full score, 1970; b) Earle Brown, December 1952, full score, 1952; c) Maurizio Sacripanti, plan of the Opera House, 1964.
Fig. 9. a, b) Jacques Polièri Enzo Venturelli, Thèatre du Mouvement Total, 1963; c) Josef Svoboda, plans for a multi-purpose theatre in Prague (end of 60 s) to 1978, Xenakis will continuously test his Polytopes (fig. 7), synesthetic spatial conceptions of space, sound and light, rationally anticipating certain Dionysian outcomes, that the first epic concerts of groups, such as The Rockets, the Kraftwerks, the Tangerine Dreams (not counting Pink Floyd and Brian Eno), would have written in the history of the show: from the I 200 lamps that in 1967sparkled at rhythms and algorithmic frequencies in the Polytope of Montreal, to the use of the first laser rays in the Polytope of Cluny (Paris, 1972), not before having passed through the Hibiki Hana Ma sound carpet, recorded at the Osaka Exhibition in 1970, that same Expo for which Maurizio Sacripanti designed the Italian Pavilion, a visionary architecture in motion.
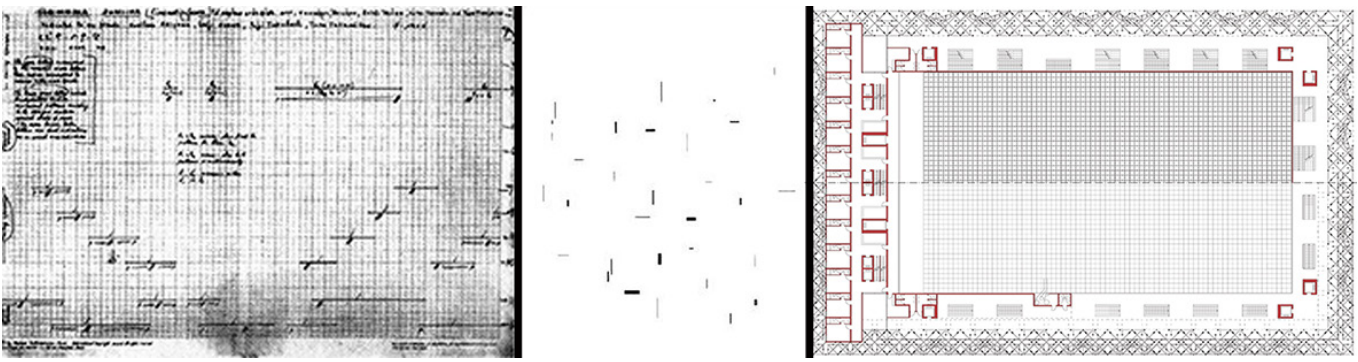

The score of Hibiki Hana Ma (fig. 8a) seems to be inspired by the more rational and at the same time physiognomic Sacripanti's attempt, the Cagliari Opera House (1964), a changing carpet (fig. 8c), comparable to the configurations of Earle Brown (fig. 8b) or Sylvano Bussotti (fig. 3c): a space-sound continuum, designed to accommodate any design gesture in a kind of controlled freedom, reminiscent of the nitor of Mies van der Rohe, also interpreter of an experimental theatre for Mannheim (1952), but also of the random procedures mentioned above.

Two directors, protagonists of the Twentieth Century theatre, Josef Svoboda and Jacques Polièri, in addition to their numerous shows, do not fail to design stage spaces, according to a logic that we would call today 'concept'. Centric theatres, such as the Thèatre du Mouvement Total (figs. 9a, 9b) that Enzo Venturelli designed for Polièri in 1963 (similar to Gropius'
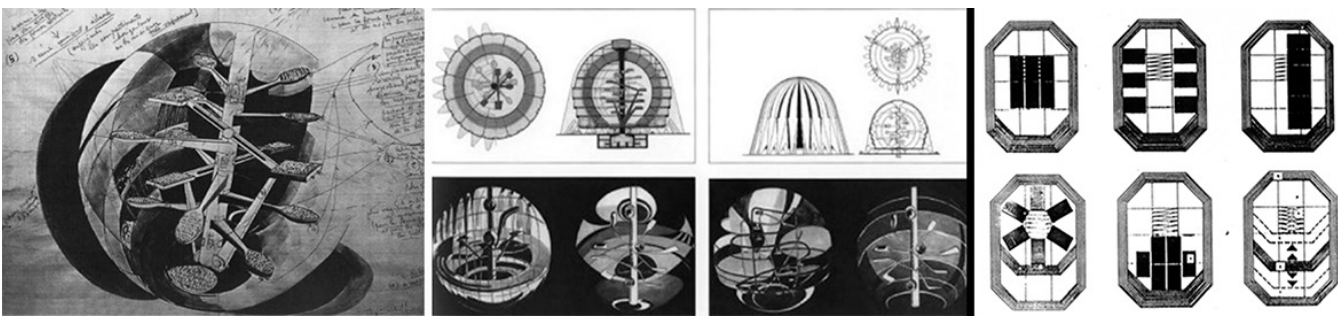

one for Piscator), or changing theatres, such as the one designed by Svoboda for Prague at the end of the 60s (fig. 9c), anticipating certain scores that Pierre Boulez in the mid-80's would have perfected in carnets of musical/spatial indications (fig. 10), as in Dialogue de l'ombre double (1985).

This contribution is decisive for the design of the house of the IRCAM in Paris, expressly designed by Renzo Piano and Richard Rogers for Pierre Boulez and his Ensemble Intercontemporain.

Hyperdeterministic approach, radically opposed to the cells of the auditorium project in Gent, by Andrea Branzi and Toyo Ito, a 'sound sponge' showing extraordinary analogies (fig. II) 
Fig. 10. Pierre Boulez, two pages of the score/ project Dialogue de l'ombre double, 1984.
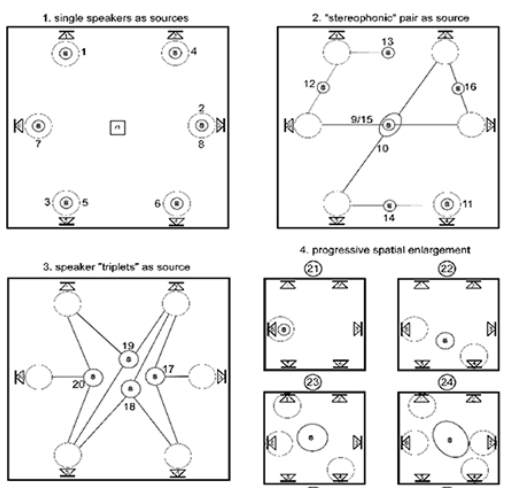

Ker:
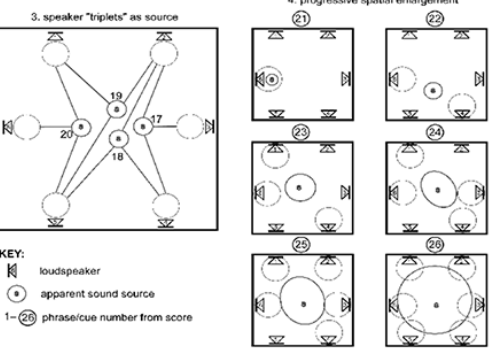

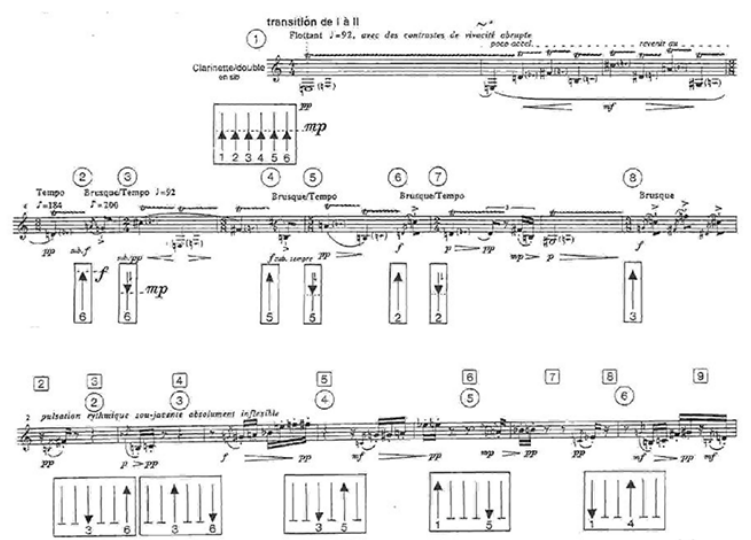

with globular clusters of certain scores by Mauricio Kagel (Transición II, 1958) and Karlheinz Stockhausen (Zyklus, 1959).

Moreover, Stockhausen himself, discoverer of the 'white sound' (acoustic analogue of the visual phenomenon of the additive syndrome of light), in Tunnel spiral (1969), echoes the ancestral forms (fig. I2) of Megalopolis hypostile Thersilion (IV sec. a.C.).

A path that therefore proceeds by successive incarnations, in which notation and architecture are designed and noted reciprocally. Architectures, all those we have referred to, almost always remained on paper, but ascribable to the world of Ideas, just like that impalpable music to which reference has been made, that exists, but is intangible, recovering a sort of ancestral mapping.

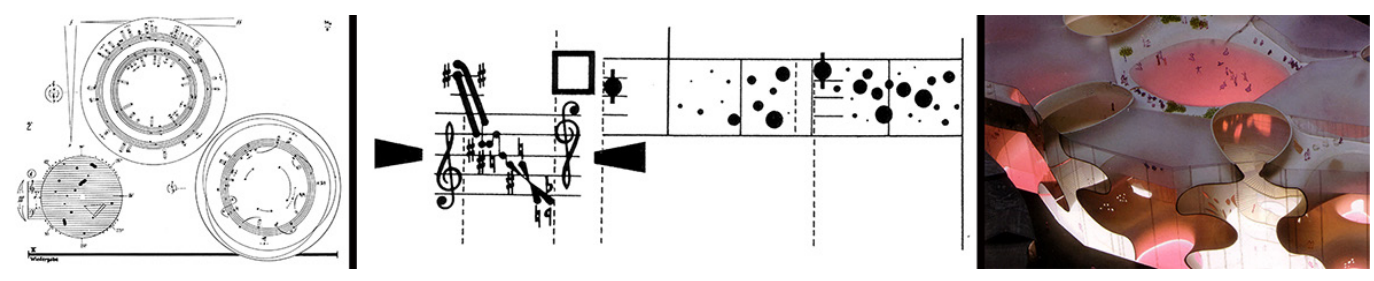

Xenakis remarks as follows: "The artist plays with shapes just like the scientist or the religious. The musician does the same in an even more systematic way, as he simultaneously lives in the microcosm of sound and in the macrocosm of the larger architectures, as if he were in a millefeuille, made of transparent layers in all senses" [Pierangeli 20 I5].
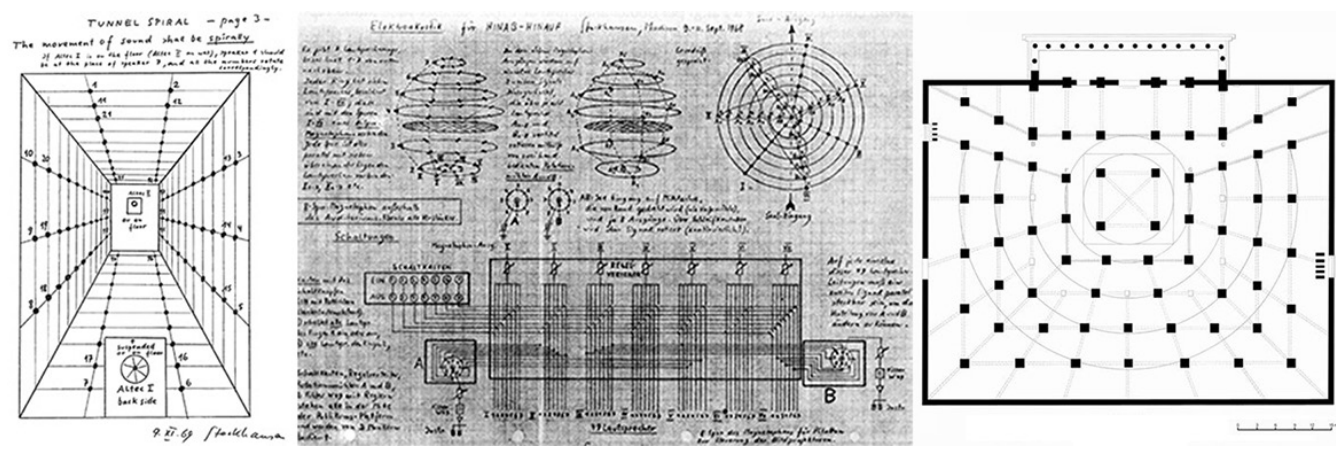

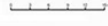

Fig. 12. a) Karlheinz Stockhausen, Tunnel Spiral full score (1969); b) KarIheinz Stockhausen, appli-
cation of Tunnel Spiral to the circular plan of Osaka Expo; c) Megalopoli, plan (IV sec. a. C.)
Fig. I I. a) Mauricio Kagel, Transición II, full Stockhausen, Zyklus, full score, 1959; c) Andrea Branzl, Toyo Ito, plastico for Gent Auditorium 


\section{References}

Boulez Pierre (1957). Alea. In La Nouvelle Revue Française, n. 59, pp. 25-29.

Busoni Ferruccio (1906). Entwurf einer neuen Ästhetik der Tonkunst. Leipzig: Zweite, erweiterte Ausgabe.

Centineo Santi (2006). Representamen. II ruolo dell'Architettura degli Interni nel ripensamento del rapporto musicalarchitettural società. Dottorato di Ricerca in Architettura degli Interni e Allestimento, Politecnico di Milano, XX Ciclo. Tutor: prof. Andrea Branzi.

Centineo Santi (2007). Cave caveam. In Branzi Andrea, Chalmers Alessandra (a cura di). Spazi della cultura, cultura degli spazi. Nuovi luoghi di produzione e consumo della cultura contemporanea. Milano: FrancoAngeli, pp. I33- I 48.

Ferrero Lorenzo ( I97| ). La fabbrica dei suoni. In Pianeta, n. 43, pp. I I-2 I.

Fugazza Gian Felice (1983). Elettronica, Musica (ad vocem). In DEUMM (Dizionario Enciclopedico Universale della Musica e dei musicisti), vol. IV,Torino: UTET, pp. 256-278.

Gentilucci Armando (1972). Introduzione alla musica elettronica. Milano: Feltrinelli, pp. 128.

Lanza Andrea (1983). Alea (ad vocem). In DEUMM (Dizionario Enciclopedico Universale della Musica e dei musicisti), vol. I, Torino: UTET pp. 59-60.

Lanza Andrea (1983). Notazione (ad vocem). In DEUMM (Dizionario Enciclopedico Universale della Musica e dei musicisti), vol. IX, Torino: UTET, pp. 338-367

Pierangeli Fabio (20I5). lannis Xenakis. La legende d'Eer. <https://www.ondarock.it/speciali/iannisxenakis_lalegendeder.htm>.

Pousseur Henri (1976). La musica elettronica. Milano: Feltrinelli.

Prieberg Fred K. (1963). Musica ex machina.Torino: Einaudi. (I Ed. (1960). Musica ex machina. Über das Verhältnis von Musik und Technik. Berlin-Frankfurt-Wien:Verlag Ullstein

Sacripanti Maurizio (1973). Città di frontiera. Roma: Bulzoni

Svoboda Josef (1989). Architetture dellimmaginario. Milano: Ubulibri.

Xenakis lannis (2006). Musique de l'architecture. textes, réalisations et projects architectureaux choisis, présentés et commentés par Sharon Kanach. Marseille: Éditions Parenthèses.

\section{Author}

Santi Centineo, Politecnico di Bari, santi.centineo@poliba.it

To cite this chapter. Centineo Santi (2020). Archi-partiture. Sperimentazioni e corrispondenze fisiognomiche tra notazione musicale e architettura teatrale nel '900/Archi-scores: physical experimentation and correspondence between contemporary musical notation and theatre architecture. In Arena A., Arena M., Brandolino R.G., Colistra D., Ginex G., Mediati D., Nucifora S., Raffa P. (a cura di). Connettere. Un disegno per annodare e tessere. Atti del $42^{\circ}$ Convegno Internazionale dei Docenti delle Discipline della Rappresentazione/Connecting. Drawing for weaving relationships. Proceedings of the 42th International Conference of Representation Disciplines Teachers. Milano: FrancoAngeli, pp. $1045-1062$ 